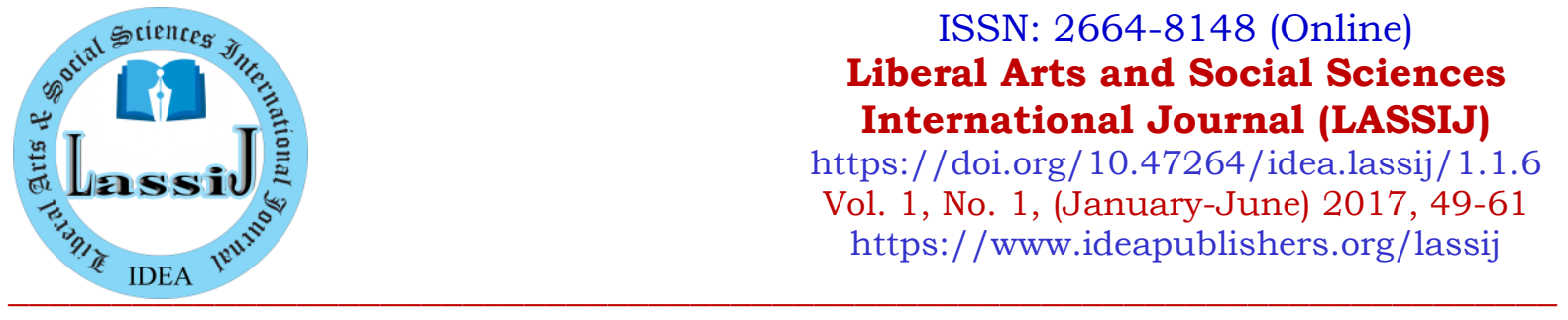

\title{
Changing Dynamics of Global Politics: Transition from Unipolar to Multipolar World
}

\author{
Muhammad Muzaffar ${ }^{1}$, Zahid Yaseen ${ }^{2}$ and Nazim Rahim ${ }^{3 *}$
}

1. Department of Political Science and International Relations GC University Faisalabad, Pakistan.

2. Department of Political Science, Government Post-graduate College, Gujranwala, Pakistan.

3. Department of Political Science and International Relations, Qurtuba University of Science and Information Technology, Peshawar Pakistan.

\begin{abstract}
World is transforming again from unipolar to multipolar. Many regional powers are emerging on the canvas of international politics. Complex interdependence has taken its place and due to this phenomenon old rivals are now making alliances and friendships. Not even a single state can afford to exist in isolation. Keeping this entire scenario in view this study analyses the future of world politics at extent of political interaction and the next power structure of $21^{\text {st }}$ century. In Past, the order of polarity shifted from bipolar to Unipolar as considered the transition of power in international world. The increasing trends of multipolarity have been allied with these three factors: The end of US hegemony, the peaceful rise of China and other emerging states in different regions, and the shifting nature of power structure from Unipolarity to Multipolarity. This study is qualitative and analytical predictive which is employed to develop and substantiate arguments. The spectacles of modern-day noticed that the peaceful raise of China as foremost new power effect the configuration of international politics. Last decades showed the most rapid economic rate of China. Revivalism of Russia and rise of other states including China will soon overtake the US hegemony. The theoretical framework provides the basic assumptions of this transition of Unipolarity to Multipolarity due to emerging trends of international relations.
\end{abstract}

Keywords: Complex Interdependence, Long Cycle Theory, Power Transition, Unipolarity, Bipolarity, Multipolarity, Universality.

\section{Introduction}

There is a strong correlation between unipolarity and great power emergence. Late seventeenthcentury England and Austria and late nineteenth-century Germany balanced against the dominant pole in the system. Moreover, even when great power emergence was not driven primarily by the need to counterbalance the hegemon's power, the shadow of pre-eminence was a key factor. US and Soviet Union emerged as superpowers after the Second World War which shaped the power system in a Bipolar World. The bipolarity since 1945 did not last long, suggesting that the optimum balancing that realist's talk about has never been a permanent state of affair (Paul, Wirtz \& Fortmann, 2004). Bipolar system is one in which resources are evenly divided. Again, the empirical meaning of such a consequence must be tempered by those features of reality which we do not consider. It nevertheless would follow straightforwardly 
from almost any reasonable probabilistic adaptation of our model that as the expected values of the resources of two countries in a two-country system become equal, the probability that one country will succeed in any attempt to become a hegemon will decrease. The collapse of the Soviet Union shook up the international system which had been in place for four decades. The emergence of the US as the sole superpower, and the unilateralist propensities in its actions in the international arena, have given rise to a debate on the nature of hegemony and the need to work towards a more equitable international order in the twenty-first century (Chari, 2008). The September 11 attacks on the World Trade Centre occurred just twelve years after the fall of the Berlin Wall and the disappearance of the Soviet Union. As the only remaining superpower, the US has been facing a violent multipolar world and has become the target of increasing threats from terrorist extremists (Mansbach \& Taylor, 2017).

Today's power structure is Unipolar (but declining) as it consists of one sole superpower, the US. The question often speculated is that how superpowers attain their position of supremacy. A nation needs solid economy, overwhelming military, political power, and strong ideology to become a superpower. US appear as superpower on the map of world due to its prestigious economy. Nonetheless, the existing power structure is of democratic line (US as single superpower) which in future is going to be converted into multi-polarity (as a world of peers with different great powers e.g., China, Russia, etc.). History is evident that the possessing powers were the inventors of wars mostly, for the purpose of getting title of superpower including Greece and Persia. German hegemony in $20^{\text {th }}$ Century is its finest example. As US is following the same line; from fetching to superpower up till now, she has been the motivator of sum of wars. The innumerable fluctuating skirmishes of US starting from rebellions in negligible states to its intrusion in South Asian countries. The foremost embraces wars in Korea, Vietnam, Iraq, and Afghanistan.

In many regions, ethnic and religious conflicts are eroding the state system of government. We have both a unipolar international system (US as single superpower) and violent multipolarity (due to terrorist groups and war on terror phenomenon). The problem is to link the two symbiotically and make the world safe for such diversity and diversity safe for the world. The events of September 11 triggered extreme rhetoric about the world order, especially the place of the US in it, and the superiority of American ideals of democracy and freedom. The unprecedented attacks on the American homeland prompted President Bush and his advisors to focus on basic ideas and has increased their tendency to find solutions to international problems from a military perspective. This rhetoric and the resulting militaristic foreign policy have fuelled anti-Americanism across the world, especially among the Muslims. President Bush described himself as a "unity, not a dividing line," but when he got involved in a global open war outside of the US, fears of his intentions spread.

Like the past, the emergence of new political actors like Russia and China and many other emerging economies would form an alliance to oppose the US. The emerging regional powers are trying to strengthen their sovereignty in world politics because of their capabilities. The current period of transition and balance of power shows the struggle of emerging state trends to conquer their position in the world. At present, it can be examined that China's peaceful rise as the new power fastest economic pace is influencing the pattern of international politics. The revival of Russia and the rise of other countries, including China, will soon overtake American hegemony (Paul, Wirtz \& Fortmann, 2004). While classic balance theorists such as Morgenthau claim that multipolar systems are more stable than bipolar systems, Waltz takes the opposite argument. The main feature of the post-1660 great power scene was the maturation 
of a truly multipolar system of European states, each of which was increasingly inclined to make decisions about war and peace based on "national interests" rather than transnationally and religiously (Jackson \& Towle, 2006).

\section{World Power Structure: A Theoretical Framework}

The diversity and complexity about interdependence have been one of the distinctive hallmarks that we observe in international relations. Human history is evident of rise and fall of powers. As Voltaire quoted that: History is filled with the sound of silk slippers (US as Super Power/ strong economy) going downstairs and wooden sandals (other emerging states China, Russia, India, Germany, Turkey etc. growing in economy) going up. The major reason of these downstairs and upstairs of silk slippers including war, socio-economy, political unrest, and other factors. The emergence of non-state actors and threat ensued are also the basic features of the current trends in international relations. The upward stairs of wooden sandals according to Voltaire, helps to shift the order of political world through different means is sign of 'power transition.' The Roman Empire and several other empires in different regions of the world lasted over 300-500 years. In the modern international system, imperial powers such as Britain survived over 200 years with its hegemony waxing and waning over time. American hegemony marks the achievement of long-term strategic goals. Since the early 1940s, the US has been trying to create a unipolar power structure in the international system. In the three major regions, the Western Europe, the East Asia and the Persian Gulf, it has simultaneously maintained a permanent military presence to prevent the emergence of new poles of power. US wants to establish regional stability, arguing that it is necessary to defend an international order dominated by US, by replacing more or less anarchy with a hierarchy in these regions.

No doubt, the US has arose as a unique balancer as finally, it has ended the carnage. There is no question that the US from 1916 to 1945 fulfils the criteria by which we call it a unique balancer. This was demonstrated during the First World War in 1916-18 and, again, during Second World War in 1941-45. Indeed, it is precisely the period from 1921-40 when the US could have acted as unique balancer but chose not to do so (for domestic political reasons that fall outside the purview of our analysis); that the most egregious disturbances of international equilibrium took place. Since 1945, a bipolar system has emerged, albeit this system is showing increasing tendency toward multipolarity. However, it is unclear exactly to what degree the US could be said to be a unique balancer within a multipolar system in the nuclear age. The existence of nuclear weapons and intercontinental delivery systems for such weapons renders our discussion of geographical contiguity and no contiguity moot; if one can deliver several thousand megatons of nuclear destruction to any country on the globe within half an hour - and this is the case for the United States and the Soviet Union, and somewhat less so for China, Great Britain, and France. There seems to be little relevant sense in which geography introduces discount parameters for force projection by any nuclear power. If such a system is, however, system stable - and whether it is or can be system stable is outside the purview of our current discussion - then the role of the balancer, if not the unique balancer, remains of crucial importance (Niou, Ordeshook \& Rose, 2007).

Balance of Power Theory is one of the most primogenital and durable notion in politics of $21^{\text {st }}$ century international relations. In fresh retro, this is the most reliable approach among influential and hostile states. The astonishing situation seems at the end of Cold War when subtleties of power balancing have been there, but the union of great powers is absent to counterbalance the US preponderance. In Unipolar world, the states are chasing range of 
security tactics counting "soft balancing." China is trailing a subsidiary balance over internal armaments and tries to get dominance over US (Smith, 2012). The research study with the implicational phenomena of Balance of Power brings the International Power Structure at equilibrium state. To balance the power in International System; the union of China, Russia, and likewise other Arab countries and India can compete the US to an extent. China believes that it is her time to declare that world has two superpowers and is going to replace Russia on the world map as a claimant of bipolar world. Therefore, China is making the best military and at same time working to expand its financial boundaries beyond its surplus budget.

This power distribution is known as polarity in international system and it denotes, how power is balanced among states. Polarity differs as Unipolarity, Bipolarity, Multipolarity and universality. Universality means there is no hierarchical order in the world and there is no security and power issue which is not applicable in the world. Nineteenth century marked as a Multipolar system due to numbers of influential actors in world politics. In Multipolar power structure, three or more states intermingle and often make alliances for making balance among them. The strongest state will not form an alliance. As a superpower one or more can be capable to influence the policy of world on a larger scale. During WWII, the three great powers US, Britain, and USSR fought for peace but tangled later in fight of economic, political, and militarily power. With the end of War, Britain roofed with $25 \%$ land with same amount of population. However, Britain lost her power; and both US and USSR were evolved as major new superpowers (Pearson Global School, n.d).

Before the Cold War, US was the world leading producer but at same time USSR was employing her five-year plan to improve economy. US entered in the Second World War to save the capitalist investment in Europe (Thomas \& Sacko, 2007). Despite the collapse of Soviet Union its descendant Russia stands in international politics more aspiring and insistently. The credit of growing economic and opportunities for development, which reemerged Russia goes to the "Strong Man" and inspiring leader "Vladimir Putin." Russia rightly conducts the tireless stress of financial agreement executed by European states (Akan, n.d). Russia has strong stance of multipolar world as it is a source of allocating it a new position in international politics. The argument, whether world is in transition from Unipolar to Multipolar system, is supported by the fact that Russian economy is parallel to Chinese economy. Even though, beside numerous whoopla operations of Russian economy, it is closely associated with West and provides a proposal of "Development Model" for developing countries. Russia does not posture any military threat against the West but decodes its power to strengthen economy to determine its aptitude to impact others.

\section{Methods and Materials}

Keeping in view the nature of the study qualitative method is used with an analytical approach. The primary and secondary sources are used as a mixed method approach. Primary sources were the reports of government as well as the international organisations especially in economic activities in International politics. Books and research papers were used as secondary sources that helped the researchers to reach the exact results and prospects of transition system towards multi-polarity. The analytical discussion has been divided into four parts. The first section analyses the current state of economy and the military strength of the US. The second section deals with the newly emerging powers like China and Russia along with their prospects of becoming superpowers. The third section discusses the growing trends of regionalism in the world system and the possible alliances of emerging multi powers to counter the US hegemony 
in near future. Fourth section gives analytical view about the transition of power in line with the long cycle theory which is reshaping the world order into a multipolar system. The key findings of the study have been summarised in conclusion.

\section{Discussion and Findings}

\subsection{An Overview of US Economy and Military Strength}

Discussions are done on the US current economic situation since the Obama left the office. Not only health care, but also to overcome unemployment was one of the main agendas of 2016's presidential elections. US has been facing economic challenges and looking for markets in other parts of the world. After the seven years' financial crises, US economy is robust in private sector employment, reduced unemployment, well-designed investments in infrastructure, skills, and green growth. According to the 2016 report by Organisation for Economic Cooperation (OECD), the US economy have certain challenges such as: weak global growth, overburdened monitory policy, financial risks, and incomplete financial exchange. These are only policy challenges to current economic situation of US. In productivity US is facing numerous challenges including poor state infrastructure and pollution, weakened entrepreneurship, less production and less market power. In growth lacking, they are facing several challenges as well: poor families' lack of opportunity, slow pace of women's opportunities, social and racial inequalities, population ageing and high carbon mission's risk (World Economic Outlook, 2017). The following figure shows that since 2016's first quarter, the US economy is not stable and there is high change rate specifically after 2016 presidential election (BEA, 2014).

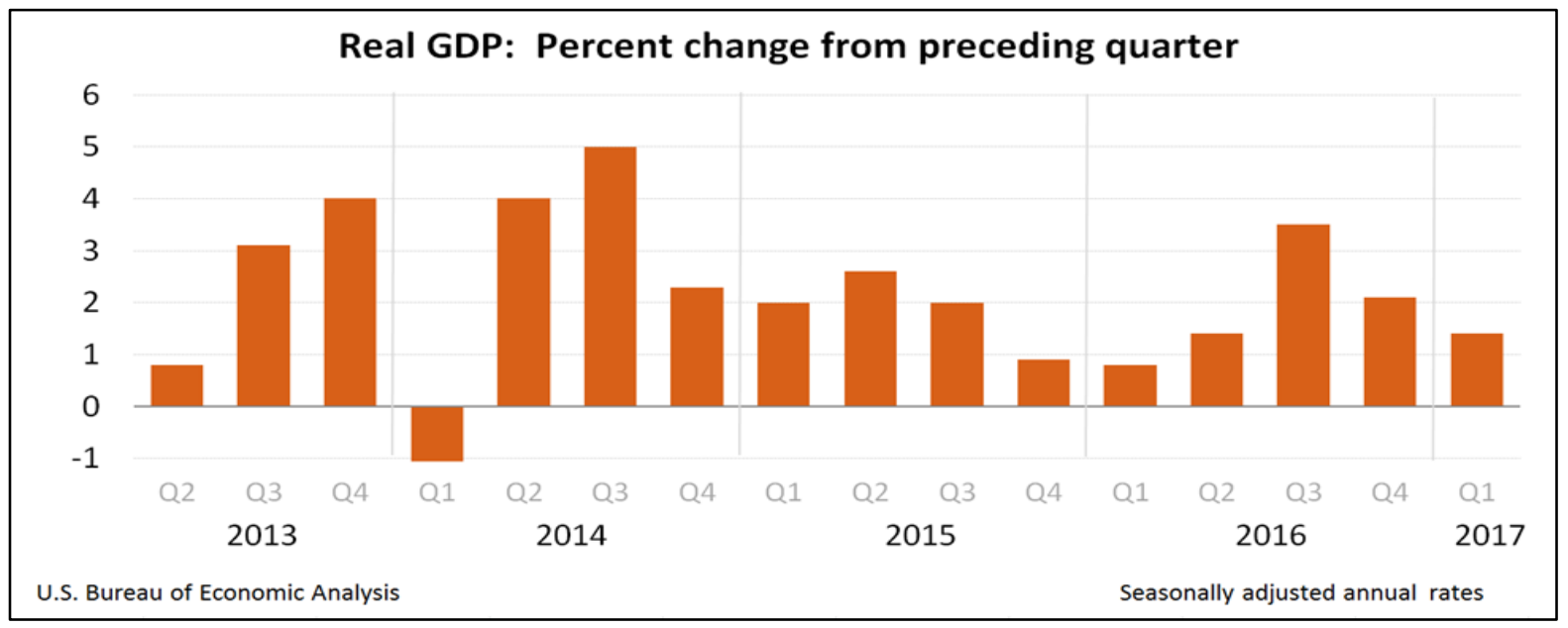

Source: https://www.bea.gov/newsreleases/national/gdp/gdpnewsrelease.htm

"US is a global power with global interests and military is meant first and foremost to defend US from attack. Besides that, it is meant to protect US interest abroad, its allies, and the freedom to use international sea, air, and space while retaining the ability to engage in more than one major contingency at a time. US must be able not only to defend itself and its interests, but also to deter enemies and opportunists from taking action that would challenge US interests, a capability that includes preventing the destabilisation of a region and guarding against threats to the peace and security of US friends" (Wood, 2016). The progress of US military effect international bred out of a number of doctrines including The Monroe Doctrine of 1823, The Truman Doctrine of 1947, and The Nixon Doctrine of 1969 and The Reagan Doctrine of 1980. 
"The US has world's largest and technologically advanced fleet of warplanes, ships, tanks and weaponry system which gives it dominance over land, sea and air. Control of space and information are basic aspects of US military strategy for $21^{\text {st }}$ century. The knitting thread in the US military presence include overseas bases, ships and crafts which allow US to apply force to any part of world, the stock of weapons and military training to many states, and network of listening posts to gather important information. The annual spending of military increased $\$ 100$ billion a year but federal funding is $\$ 40$ billion a year. The institutions and organizations which have developed over 50 years of intensive military spending have created vested interests with huge political clout" (Wood, 2016).

The Secretary of Defence Les Aspin accompanied Bottom-Up Review in 1993 and documented the "intense fluctuations ensued in world at the end of Cold War" and stems an imperious "to re-evaluate all defence model, strategies, and agendas from the ground up". The Bottom UpReview recognised the necessities that US forces should be capable to accomplish conclusive triumph in two approximately instant major regional conflicts and conduct contest manoeuvres categorised by quick reaction and great prospect of success whereas curtailing the hazard of US causalities. The independent National Defence Panel (NDP) supplemented in 1997, 2010 and 2014 have directed the Quadrennial Defence Reviews (QDR) since 1997. Both documents assist as a crucial valuations but analysts lessen their standards by concerning them as justification for executive branch policy inclinations (QDR Report) but comprehensive interpretations (NDP Report) which deficiency is applicable debate on US threats, reliable approach for dealing with them and the concrete capacity of US military to encounter national security. In FY-2015 the base line budget for defence was $\$ 522$ billion but it does not pay for enduring operation which seized an extra funding known as Overseas Contingency Operations (OCO). Budget Control Act (BSA) was foiled via who is afraid of dropping apparatus that disciplines federal spending. BCA asked for more money to fulfil the defence requirements for FY-2016 funding from the White House and both chambers of Congress (Wood, 2016). Following figure shows that as compared to FY-2014, the defence budget is $\$ 1$ billion more in FY-2015 to accustom the inflation. The FY-2016 was $\$ 561$ billion under Presidents request which would be $6 \%$ increase over FY-2015.

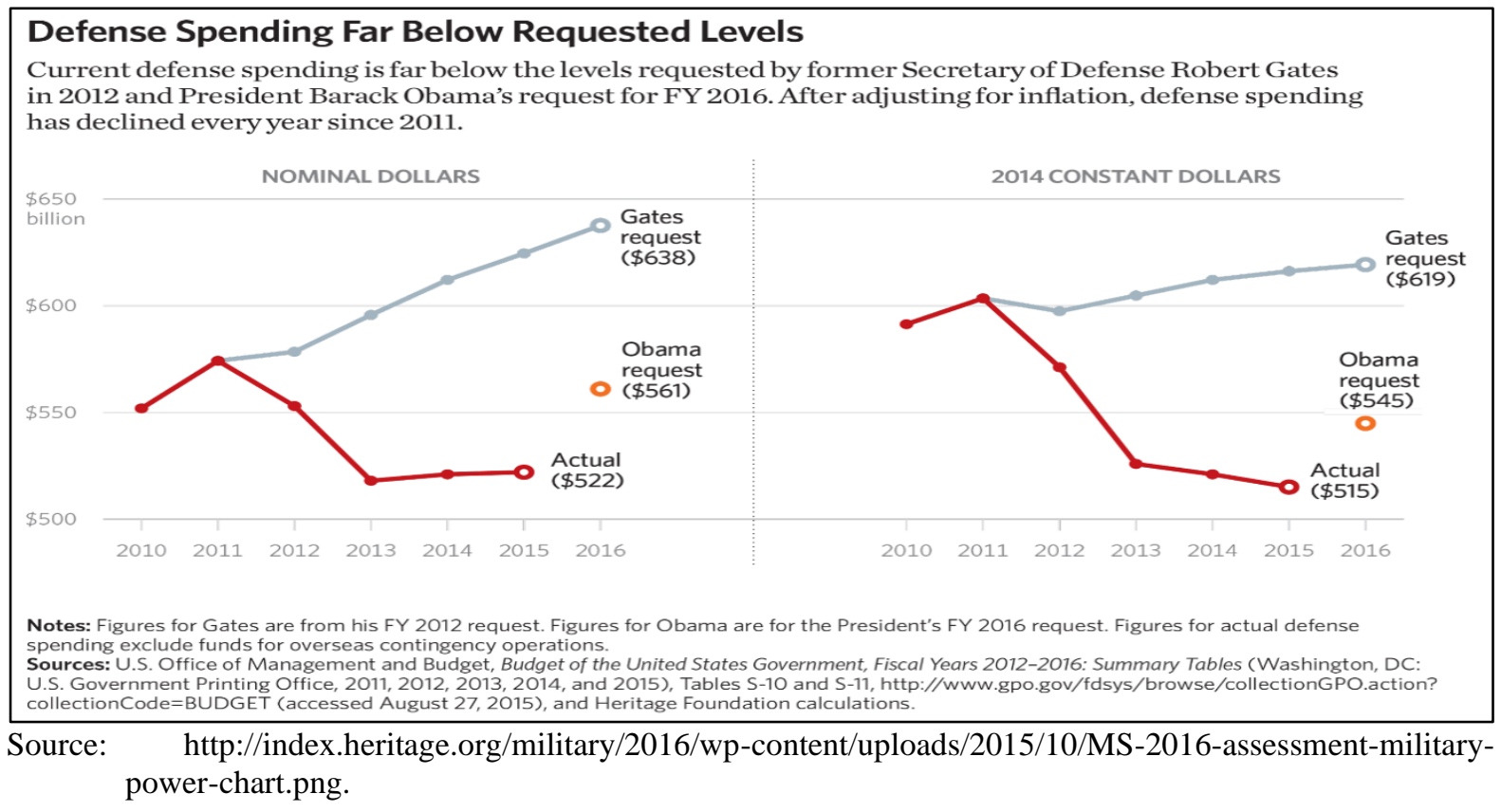




\subsection{Emerging Powers of $21^{\text {st }}$ Century}

The allegations on diverse features of Chinese development from military and power extension to increasing energy demands are the most discussed topics among international community (Gifford, 2008). Let us take it from 1978, China has 9.4\% annual GDP growth which is highest growth rate in the world economy. Moreover, its foreign trade was $\$ 20.6$ billion. During the late twentieth century, China hardly had mobile telecommunication services. Now it has more than 300 million mobile phone subscribers in the world and more than 100 million people have access to the internet. Besides all fiscal crisis, Chinese macro-economic management is highly proficient to discharge from the crisis as seen during Great Recession (2007-2009) which is highly appreciable. China introduces its domestic consumer sector to make strong and welldeveloped domestic market. The billionaires' contracts of China and development of non-fossil fuels under $12^{\text {th }}$ five-years plan can make it a leader in world of energy politics in near future. More than half of the economy of China is based on the private entrepreneurship which adds more to its economic stability (Cooney \& Sato, 2008).

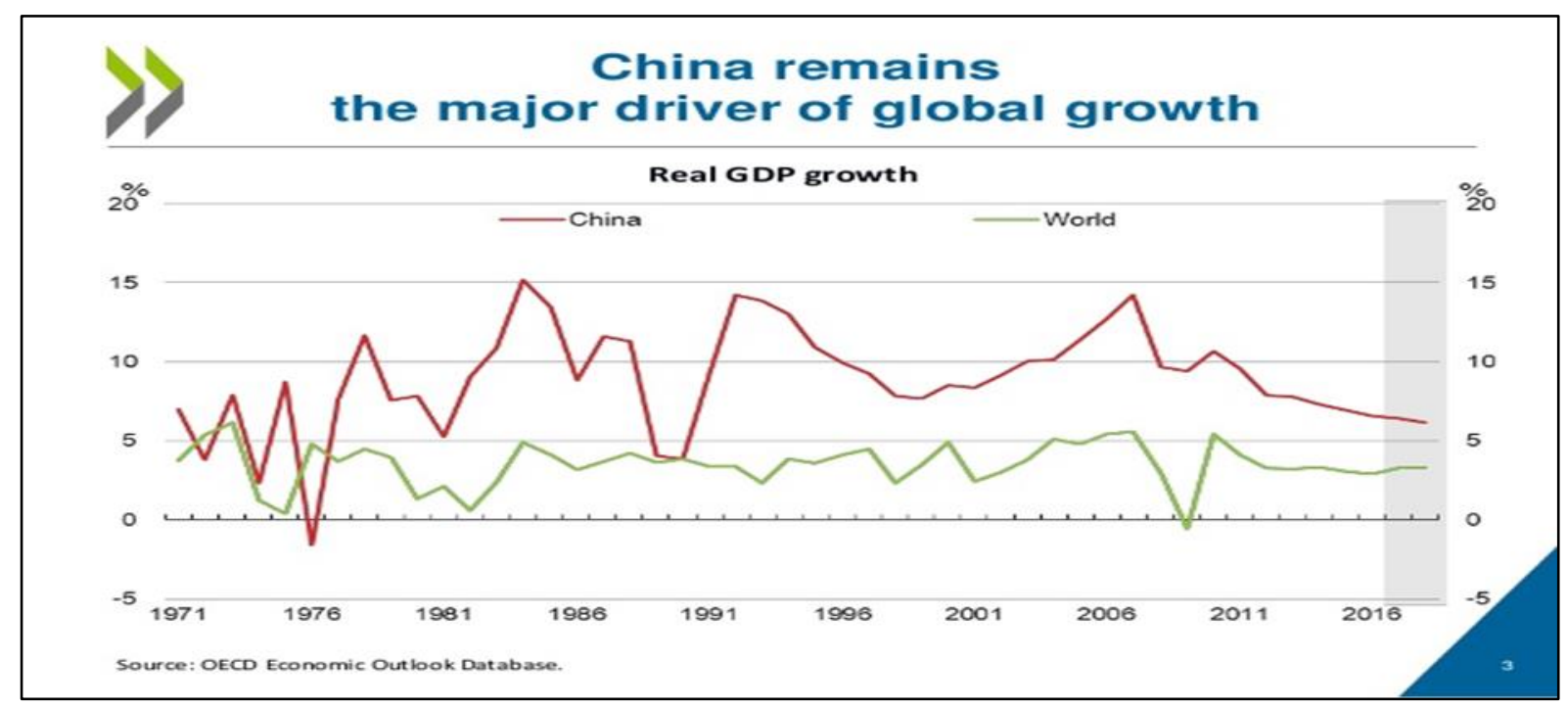

Source: OECD Economic Outlook Database

International Monetary Fund (IMF) ranked China as number one economic power in the world by asserting that it produced 17\% of the GDP in 2014 more than US GDP $16 \%$ in the world. The $12^{\text {th }} 5$-years plan stressed upon development of renewable energy to fulfil $15 \%$ need of the state by 2025.This policy will contribute to prevent environmental degradation and clean air. Chinese economy lingers to grow steadily by international standard as it enters $13^{\text {th }}$ five-year plan (2016-2020) as a result it will remain major global superpower in near future (Jacques, 2009). According to UN, China is world's biggest merchant marine operator and custom admiration demonstrates that 40,000 ships enter and left the Chinese ports. China's changing approach of inter-governmental partnership and connectivity to sponsor economic catch-up of low and middle revenue/income states like Latin America, Brazil, Argentina, Columbia and India (which also has large population) inspired its performance. It has been forecasted that in near future, the GDP gap among China and other great states of the world will further widen and may provide it an opportunity to inaugurate major international economic development programs (Jacques, 2009).

The universal phenomena of corruption have its roots in every state but in China the corruption 
rate is low as compare to other states. In recent few years several high-level officials have been removed from offices, imprisoned and even few are sentenced to death penalty due to legal charges of corruption. The government of China drives serious anti-corruption policies which demonstrates that it will succeed soon; to clean up the state from corruption. The hallmark of China's leadership verdicts is philanthropy, social perceptions, democratic motives, equality, economic expansion, and public service. The unique socio-economic political system of China illustrated by free competitive market economy and duel system of one political party, the $20 \%$ of Chinese population have been lifted out of poverty (Jiang \& Kmaraney, 2015). China introduced new international and economic political order which was obtained through democratisation of international relations and all this development depends upon world peace (Jacques, 2009; Clegg, 2010).

The two major developments in early 2000s assisted Russian re-emergence. Firstly, Clinton's knob fingers with Medvedev pushed the retune button, and US passed on fast for expansion of NATO in Eastern borders of Russia. Secondly, the colour revolutions and Georgia War isolated Russia from international club and supported pro-Russia strongman Putin's hand. The Russian per capita GDP, under Yeltsin was $\$ 1000$ which reached to $\$ 9000$ under Putin's leadership in 2012. The total output grew by $67 \%$ and stock market capitalisation increased by 22 -folds while foreign trade turnover increased 5-folds during 2000-2008. Russia overtook Germany and became the leading economic state in Europe by obtaining the power parity in 2013. Russian re-emergence can be explored through the activities like, to become an energy superpower, internal stability by the ending the weak leadership, balance against West and salvage its impact over the newly independent states such as Belarus, Ukraine etc. These are the main dynamics towards re-emergence of Russia as a superpower. The role played by Russian President Vladimir Putin marked as pivotal in her re-emergence as he devoted on re-establishing and sustaining its impact over the world and put an attack on corruption. Putin's policy provided a base to the Russian re-emergence by rapid economic growth which is the main success of revival of its economy. The Russian economy made progress during Putin period, is appreciable as its GDP gone up 70\% and industrial growth by $75 \%$ and investment have increased by $125 \%$ and gained its place at top 10 world economies. Putin's policy gave the government the power to control an extensive part of Oil and Gas, and its revenues. By state control in these sectors, it has established fuel and energy companies which are open and transparent for the investors. The profit of Lukoil increased has by $38 \%$ and the level of Central Bank Currency rose up by $10 \%$ ( $\$ 4.8$ billion).

Russia as an energy superpower emerged in world to revive its position in international arena. For rainy days, the fund was established to collect oil revenues and within two years it stored revenue to reimburse all debts. In 2007, Russian GDP reached to 1990's level as it tried to overcome the economic crisis distressed in 1990s. Under Putin's leadership Russian economy took an upward turn by increasing oil revenues. In 2008, the investment fund during global fiscal crisis was given into reserve fund which has been intended to protect Russia from possible financial tremors. The industrial development boosted in Russia in 1998. According to Federal State Statistics Service, the industrial growth was 9\% in 2000 but it was low down to $3.7 \%$ in next few years. A new shift began in 2003 and this growth rate reached at $6.3 \%$ in 2007. The production in manufacturing was raised by $9.3 \%$, electricity production was reduced by $2 \%$ while evolution in mining was $1.9 \%$ in last year. Under Putin's leadership the proportion of population living below the poverty line decreased from $30 \%-40 \%$ in $2000-2008$ by increasing average wage from 2,200 roubles to 12,500 roubles (Bull, 2012). All the abovementioned economic U-turn made Putin's dreams of emergence of Russia successful. For both, 
Putin and Medvedev, the current international system is unacceptable as dominated by US. So, Russia's struggle shows that the population and leaders have a vision of Multipolarity (Stuenkel, 2017).

\subsection{Growing Regionalism: A Support to Multipolarity}

In this research, regionalism is the supporting factor used to solidify the argument of transition of Unipolarity to Multipolarity. Regionalism refers to the structure of views, values and objectives that materialises towards development, protection and management of a specific region or type of world order. It is a political program associated and originated since mid1980s. The European Union (EU), Association of South East Asian Nations (ASEAN), Economic Community of West African States (ECOWAS), South African Development Community (SADC), Union of South American Nations (UNASUR), South Asian Association for Regional Cooperation (SAARC) are the major example of regional organizations. Generally, this concept of politics is based on ethnicity, caste, creed, language and colour and despite having all digitalisation, modernisation and development, both the developing and developed nations observe and practice this concept of politics to secure their own as well as the regional stability and survival. There are total three waves of regionalism, namely The First Wave (1945-1965), The Second Wave (1965-1985), and The Third Wave (1985-Present).

The first wave of regionalism (1945-1965) is the evolutionary stage of Regionalism and creation of regional organisations notably the UN and the Bretton Woods/GATT system. In this period, three distinguished classes of regional institutions are classified according to their purposes and objectives as: a) Multipurpose such as League of Arab States, the Organisation of American States; b) successor to the Inter-American system and the Organisation of African Unity; c) Security alliances and accords, such as NATO and the Warsaw Pact. Economy oriented for instance the early European institutions. Nonetheless, the first wave of regionalism raises several questions after the end of World War II, there was Cold War between America and, Russia, that gives end towards the concept of first wave of regionalism that gave a new life during its $3^{\text {rd }}$ wave (Fawcett, 2008).

The Second wave of Regionalism dates back from 1965-1985. The second wave of regional institution building which occurred mainly among developing countries, had an under lying security focus, and hence was clearly distinguishable from the earlier wave of economic regionalism. This era included both a Pan-European security institution, the Commission on Security and Cooperation in Europe (CSCE), and a Pan-Islamic one, the Organisation of Islamic Conference (OIC). The more familiar examples of this second regional wave are the ASEAN, the ECOWAS, the SADC, the Caribbean Community (CC), the SAARC, the Arab Maghreb Union (AMU) and Gulf Cooperation Council (GCC).

In the new security environment after $9 / 11$, the demand that states and institutions respond to US leadership in matters about Weapons of Mass Destruction and anti-terrorist activities, provides a rational example of this. Secondly, states attach value to institutions. "Institutions are not mere by-products. Regional institutions and organisations are useful vehicles and instruments in handling a security threats and for curbing state weakness in a challenging international environment. Those states which have internal peace and a strong and independent civil society seem best placed to benefit from globalisation. The history of regionalism thus invites caution, care, and apprehensions in attributing too much activity with the concept of regional identity. More important is the need for regions and their constituent 
states to project their power and influence on regional and global stages. However, limited that power may be while attending to their security and sovereignty concerns in a way that preserves regional autonomy and order. Third Wave (1985-Present) of Regionalism presents that the International system had closely demarcated the limits and potentials of regionalism during Cold War" (Fawcett, 2008).

\subsection{The Transition of World Power Structure}

The cycle of rise and fall of nations, empires, regions, and global powers has been observed throughout the history of world. From decades, military was the only basic tool to "balancing the power" (Herd, 2010). The power structure has been more rigorous due to extraordinary developments in international arena in twentieth century ranging from Multipolar to Bipolar, in the last decade to Unipolar system (Thomas, \& Sacko, 2007). Since the end of the Cold War, the world power structure has been presenting as Unipolar and is dominated as a sole hegemonic power. The progress in framework of international system is again revolving the pin of the power structure clockwise rapidly from Unipolar to Multipolar. This shift in world's structure is done due to neo-conservative and imperialistic policies which are shaping the "Multipolar World Order." This fact supports this research under the Balance of Power Theory. The following figure presents the image of historical shift of power structure from $\mathrm{Bi}-$ Unipolarity and further this cyclic wheel will spin towards the Multipolarity in international world due to emergence of new political actors (Clegg, 2010).

Power Transition (Bipolar-Unipolar-Multipolar)

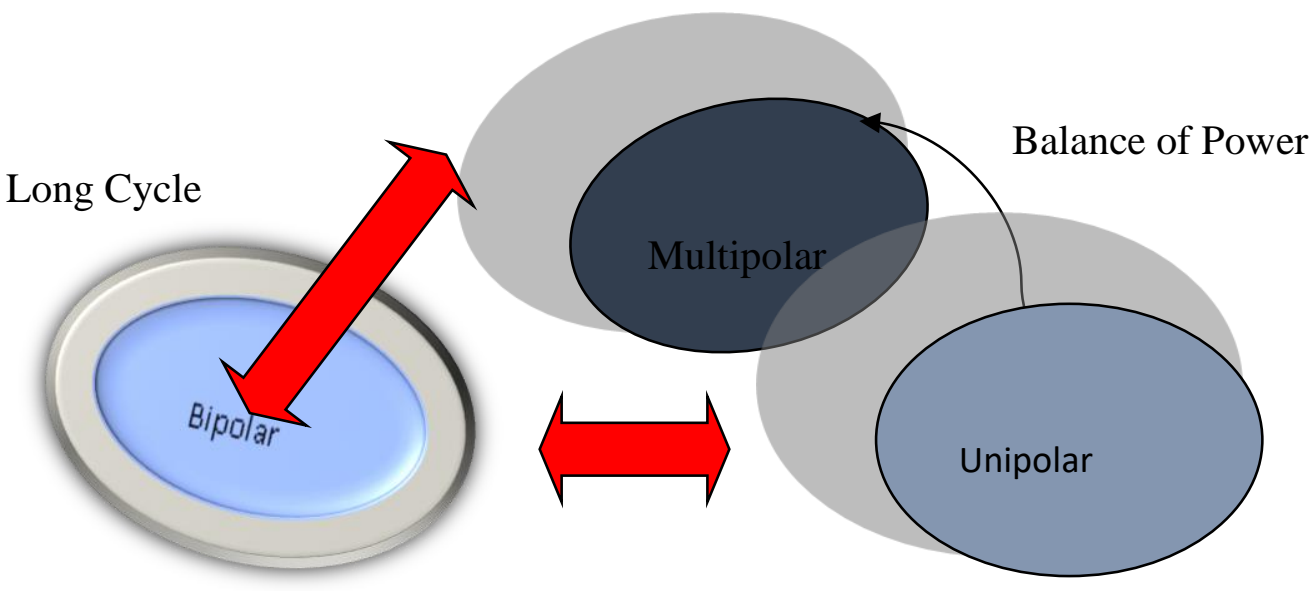

The immense economic actions by new emerging actors in international politics e.g., China, Russia, Japan, Brazil, India have stimulated the most conservationist sponsors of the argument transition of world order from Unipolarity to Multipolarity (Friedman, 2010). By living in arena of transition we witness the expansion of G8-G22, the discourse of extension in UN Security Council, professed diminution in US power, rise of BRICS (i.e., (Brazil, Russia, India, China and South Africa) and ascension of new powers all point out the factor of research argument. According to a realist Kenneth Waltz, US would not have the capacity to appreciate the product of Unipolarity for long. US, China, Japan, EU, Russia and India are accomplished economic powers due to their technical advancement, growing economies and great population along with other emerging states having more or less same qualities. This research tinted that these measures are pointed towards the emerging trends in international politics. The other emerging political actors in international ground including Saudi Arabia, Venezuela, member states of 
African Union and Iran as well as Russia would have impact due to their energy capacities. Some of the nations have significant influence in world politics due to their regional location such as Ukraine, Central Asia, Turkey and Pakistan. Due to their hold on the energy routes, they have their involvement in the affairs of international politics.

The research study focuses on the shifting of transition of world order and by making balance in international world the emerging organization play helpful role in this scenario. Examples are the major international organisation like UN, World Bank, IMF and other regional organisations like, SAARC, ASEAN, EU, SCO, ASEAN, and other non-governmental organisations. The Unipolar world is going to diminish due its weak administrational policies and weak economy which may prove to be harmful for snatching the tag of Superpower efficiently (Men \& Shen, 2014). In fresh retro of transition, states are trying to adapt their movements for domestic change and change in legislation. The notable changes recorded in $21^{\text {st }}$ century are social, fiscal, and political domains of universal design. The multifaceted state of development with an increasing pressure, the period has considerable influence in regional stability and global security in general. So, states trying to counter these fears are struggling for the balance of power and support the transition in world politics (Murray \& Brown, 2012).

\section{Conclusion}

The study made an analytical discussion on the emerging trends of international relations; Unipolarity to Multipolarity. The findings of this research reached on the final conclusion that the world will transit from Unipolar to Multipolar. This is because new actors will replace the US and balance the world power structure by repeating the cycle of change as mentioned under Long Cycle Theory. This research study proposes four expected scenarios as follows:

a) China will snatch the batch of superpower from US due to pounding it in financial sector as the economy of China is greater than that of US. The ratio of growth of both states also collides with each other. The hectic situation occurs when both states collide and there seems possibility of the Third World War, if this would happen.

b) Second, China would not become the superpower in forthcoming years despite having all the possibilities and fulfilling the criteria of becoming superpower. This would be impossible for China to challenge the current world order due to its over population and internal grievances which may become significant challenge in the success of China to rise as superpower in the near future.

c) The third scenario is that the emergence of new political actors likes Russia and China and other emerging states would form an alliance to counter the US. The emerging states, due to their capabilities are trying to exert more influence over the world affairs. The current period of transition and balance of power shows the struggle of new emerging trends of rising states to regain their powerful position in the global world.

d) The fourth scenario is that the US hegemony will not reach to its end although it has lost the economic superiority over the world. The US is still considered as the world topmost military contender which will not allow the other emerging actors to cross her position.

It seems that the history will repeat itself and the rivalry among communist and capitalist bloc will start again. In this situation, the world will be going back to the position of being 
destabilised and ruined because these blocs will again influence the world affairs in negative way. The developing states would join them by securing their interests and in return both blocs will use them as a force against each other's interest. Although, the phenomena of long cycle, balance of power, and transition of power is feasible because the security and stability depends upon the variance. If there will be only the static system, then nothing will change which may be the most hectic situation of world politics.

The newly emerging actors do not support the current world power structure. They are trying their best to replace the US hegemony by utilising their resources in all fields. Although, they are becoming capable of beating US in technology, economy, and different other fields, they are still not capable to overcome US in military power. The research shows that the future of power structure will witness transition of power from Unipolar world to Multipolar world by any means either, adopting the method of alliances or on individual superpower status. The emerging states will develop mutual understanding to end the US hegemony in the near future.

\section{References}

Akan, M. S. S. (n. d). Re-Emergence of Russia: Challenges Within US Dominated Unipolar World. Retrieved from Academia: https://www.academia.edu/9790528/ReEmergence_of_Russia_Challenges_Within_US_Dominated_Unipolar_World.

Bull, H. (2012). The anarchical society: A study of order in world politics. Macmillan: International Higher Education.

Chari, C. (Ed.). (2008). War, peace, and hegemony in a globalized world. Routledge.

Clegg, J. (2010). China's global strategy: Towards a multipolar world. Pluto Press.

Cooney, K. J., and Sato, Y. (Eds.) (2008). The Rise of China and international security: America and Asia respond. Routledge.

BEA (2014). Economic and Statistical Analysis Budget. Retrieved from Economics and Statistics Administration / Bureau of Economic Analysis (BEA). http://www.bea.gov/about/pdf/ESAFY2015CJFinal508Complain.pdf

Fawcett, L. (2008, August). Regionalism in world politics: Past and present. In Elements of Regional Integration (pp. 13-28). Nomos Verlagsgesellschaft MBH \& Co. KG.

Friedman, G. (2010). The next 100 years: A forecast for the $21^{\text {st }}$ century. Anchor.

Gifford, R. (2008). China road: A journey into the future of a Rising Power. Random House Incorporated.

Herd, G. P. (2010). Great Powers and Strategic Stability in the $21^{\text {st }}$ Century: Competing visions of world order. Routledge.

Jackson, R., and Towle, P. (2006). Temptations of power: The United States in global politics after $9 / 11$. Springer.

Jacques, M. (2009). When China rules the world: The End of the Western World and the Birth of a New Global Order. Penguin.

Jiang, F. and Kmaraney, N. M. (2015). The World Post. China's Rise to Global Economic Superpower. Retrieved from Huffpost: https://www.huffingtonpost.com/nake-mkamrany/chinas-rise-to-global-eco_b_6544924.html

Mansbach, R. W., and Taylor, K. L. (2017). Introduction to global politics. Routledge.

Men, J., and Shen, W. (Eds.). (2014). The EU, the US and China: Towards a New International Order? Edward Elgar Publishing. 
Murray, D., and Brown, D. (Eds.). (2012). Multipolarity in the $21^{\text {st }}$ Century: A New World Order. Routledge.

Niou, E. M., Ordeshook, P. C., and Rose, G. F. (2007). The balance of power: Stability in international systems. Cambridge University Press.

Paul, T. V., Wirtz, J. J., and Fortmann, M. (2004). Balance of power: Theory and practice in the $21^{\text {st }}$ century. Stanford University Press.

Pearson Global School (n. d.). Who are the superpowers and how does their power develop over time? Chapter-10, Superpower Geographies. Available at: https://assets.pearsonglobalschools.com/asset_mgr/current/201329/EdexcelA2Geog samplepages.pdf

Smith, M. A. (2012). Power in the changing global order: The US, Russia, and China. Polity.

Stuenkel, O. (2017). Post-Western world: How emerging powers are remaking global order. John Wiley \& Sons.

Thomas, S. M., and Sacko, D. H. (2007). The Unipolar World: An Unbalanced Future. Palgrave Macmillan.

IMF (2017, April). World Economic Outlook. April 2017: Gaining Momentum? Retrieved from: $\quad$ http://www.imf.org/en/Publications/WEO/Issues/2017/04/04/worldeconomic-outlook-april-2017

Wood, D. L. (2016). 2016 Index of US military strength accessing America's ability to provide for the common defence. Heritage Foundation. 